\title{
ПРИЕМЫ ОБУЧЕНИЯ СТУДЕНТОВ РАБОТЕ В УСЛОВИЯХ ИНКЛЮЗИВНОГО ИНОЯЗЫЧНОГО ОБРАЗОВАНИЯ
}

\section{METHODS OF STUDENTS TEACHING TO WORK IN CONDITIONS OF INCLUSIVE FOREIGN LANGUAGE EDUCATION}

Iu. Aparina

Summary: The article is devoted to methods of teaching students to work in conditions of inclusive foreign language education. The author proposes to use various methods to involve pupils with different levels of linguistic and general educational abilities in the educational process. The author describes the characteristics of different subgroups of students and explains how to work with them. The author demonstrates and characterizes the stages of the formation of a productive linguistic skill at the lessons of a foreign language. The article proves that the targeted teaching of students at the methodological lectures, the use of the method "Etude in the offered circumstances" will better prepare them for the forthcoming professional activity, will allow them to work fruitfully and avoid making possible mistakes under the conditions of inclusive foreign language education.

Keywords: inclusive foreign-language education, productive linguistic skills, professional activities, methods.

\author{
Апарина Юлия Игоревна \\ К.п.н., дочент, Московский городской \\ педагогический университет \\ juliaparina@mail.ru
}

Аннотация: В статье рассматриваются приемы обучения студентов работе в условиях инклюзивного иноязычного образования. Автор предлагает применение различных методических приемов с целью вовлечения учеников, имеющих разный уровень лингвистических и общеобразовательных способностей в учебный процесс. Автор приводит характеристики разных подгрупп учеников и объясняет особенности работы с ними. Автор демонстрируют и характеризует этапы формирования продуктивного лингвистического умения на уроках иностранного языка. В статье доказывается, что целенаправленное обучение студентов на занятиях по методике, использование приема «Этюд в предлагаемых обстоятельствах» лучше подготовит их к предстоящей профессиональной деятельности, позволит им плодотворно трудиться и избежать совершение возможных ошибок в условиях инклюзивного иноязычного образования.

Ключевые слова: инклюзивное иноязычное образование, продуктивное лингвистическое умение, профессиональная деятельность, методические приемы.

Современные тенденции развития общего среднего образования в России предусматривают доминирование инклюзивного обучения в условиях общеобразовательной школы. На страницах печати и в педагогических кругах не утихают споры о соотношении возможных позитивных и негативных последствий такой системы образования. Мы не станем поддерживать или оспаривать ту или иную тенденцию, мы лишь констатируем факт, что инклюзивное образование имеет букву закона, а следовательно, выпускник педагогического ВУЗа должен иметь полное представление о том, как организовать дидактический процесс в этой непростой системе инклюзивного образования [1].

Мы предлагаем педагогический прием «Этюд в предлагаемых обстоятельствах», который позволит максимально приблизить студента - будущего выпускника педагогического университета к ситуации, с которой он неминуемо столкнется в своей педагогической практике. Такого рода занятия имеет смысл проводить после изучения основ методики обучения и курса по речевому поведению учителя.

Студентам предлагают провести конкретный урок по определенной теме с определенной целью и задачами, 
однако, каждый получает карточку с характеристикой своей группы. Там может быть написано, что в его группе есть несколько детей с высоким уровнем лингвистических способностей, есть ребенок с девиантным поведением, группа слабоуспевающих детей и слабослышащий ребенок. Студент разрабатывает урок для этой конкретной группы, объясняет ход урока и его особенности, исходя из предлагаемых обстоятельств. Особое внимание уделяется дидактической речи как важнейшему средству работы с разно уровневой группой в условиях инклюзивного образования. Как отмечает в своем исследовании Петрова И.М., речевое поведение и культура речи педагога во многом будет стимулировать изучение иностранного языка [5].

Как утверждает Тарева Е.Г., только соблюдение принципа межкультурной коммуникативной компетентности позволит развить и воспитать поликультурную личность, способную гармонично и гибко существовать в постоянно меняющемся мире [6].

Проведенный урок обсуждается в группе, студенты высказывают свое мнение, выступают с предложениями. Разумеется, ряд советов и возможных приемов объясняется студентам заранее.

Прежде всего, мы объясняем студентам, что правильная рассадка детей на уроке имеет первостепенное значение. Разумеется, дети с нарушениями зрения и слуха должны сидеть максимально близко к доске и учителю. Дети с нарушениями опорно-двигательного аппарата рассаживаются недалеко от входной двери и доски. В соседи по парте таким детям следует выбрать наиболее спокойных и уравновешенных детей, которые смогут терпимо и с должным пониманием взаимодействовать со своим соседом. Особое внимание следует уделить детям с особенностями когнитивного развития и детям с непредсказуемыми поведенческими реакциями. Они должны находиться в зоне ближайшего и усиленного педагогического контроля. Правильная рассадка детей до момента начала урока позволит избежать большого количества проблемных ситуаций, способных начисто сорвать любой самый тщательно спланированный урок.

На методических семинарских занятиях студенты подробно разбирают действующие УМК, обсуждают их преимущества и недостатки, анализируют возможные пути преодоления допущенных недочетов. На каждом занятии студентам внушается мысль о том, что самое главное в профессиональной деятельности учителя это то, что он должен уметь ДУМАТЬ! Учитель никогда не должен транслировать без изменений предлагаемый материал учебника. Учебник составлен исходя из общих требований по предмету, учебной программы и рассчитан на среднестатистического ученика. При этом авторы часто ограничены количеством страниц, выбранными темами и совершенно не учитывают особенности вос- приятия материала детьми с особенностями образовательного маршрута.

На долю учителя выпадает непростая задача - адаптировать УМК к конкретному классу детей с его неповторимыми индивидуальными особенностями. И вот наш студент получает задание - проанализировать определенный урок или несколько уроков на предмет методической целесообразности и возможности применения тех или иных приемов обучения. Студент не просто транслирует цель и задачи урока, демонстрирует ход урока, но объясняет и методически грамотно доказывает возможные изменения, которые целесообразно привнести на тот или иной урок с целью достижения наиболее гибкого и вариативного подхода для достижения его максимальной продуктивности и эффективности.

Студент или молодой специалист хорошо представляет себе на каком этапе формирования того или иного лингвистического умения находятся его ученики. Этап определяет выбор технологии и приемов обучения. Этим часто грешат наши современные УМК, где на этапе ознакомления могут быть представлены упражнения и задания, соответствующие этапам тренировки и применения.

Итак, первое, чему должен быть обучен будущий выпускник педагогического университета - критически оценивать учебный материал, предлагаемый в УМК. Очень часто приходится давать дополнительные разъяснения, представлять наглядные схемы, яркие картинки, способствующие формированию яркого, легко запоминающиеся образы у детей и призванные облегчить процесс усвоения текущего учебного материала.

Учитель порой вынужден перераспределять задания, начинать тему задолго до ее появления на страницах учебника, тем самым давая возможность для более пролонгированного процесса усвоения материала. Особенно это необходимо для классов, где есть дети с особым образовательным маршрутом, а такие сейчас есть практически в каждом классе. Вот этому необходимо учить студентов на занятиях. Они должны видеть и готовить урок не отдельно, а в совокупности с другими уроками, уметь создавать систему обучения, которая будет строго следовать поэтапному трехступенчатому формату формирования продуктивного лингвистического умения. На первом этапе - ознакомления мы информируем детей о том или ином лингвистическом явлении, учим узнавать его в представленных словосочетаниях, предложениях и текстах. Очень важно учить детей осознавать ситуативность употребления того или иного явления. Пока этот этап не полностью пройден, переходить на следующие этапы - тренировки и применения, нельзя. Значительную помощь может оказать учителю использование на уроках видеоматериалов. Они имеют большой лингводидактический потенциал, поскольку благодаря видео 
наглядно демонстрируется естественный (аутентичный) процесса межкультурной коммуникации» [3].

Сложность заключается в том, что в условиях инклюзивного образования есть группа детей, которая должна более продолжительное время пребывать на каждом из этапов, особенно на самом первом - этапе ознакомления, значимость которого трудно переоценить. Соответственно, студент, планирующий не один урок, а систему уроков, распределяет, как и какие задания выполняют дети, относящиеся к разным подгруппам и находящиеся, соответственно на разных этапах формирования лингвистических умений. Давайте поподробнее остановимся на характеристике подгрупп, на которые мы условно можем разделить группу детей.

К первой подгруппе относятся активные и способные к усвоению лингвистических знаний дети, высоко мотивированные к изучению иностранного языка, легко осваивающие предлагаемый материал. Эти дети всегда занимают лидерские позиции в ходе проведения урока, стремятся отвечать первыми, быстро проходят этап ознакомления, готовы к заданиям повышенной сложности. Особый интерес у них вызывают задания продуктивного характера, такие проекты, сообщения, доклады. Эта группа непременно должна получать задания, соответствующие их интеллектуальному уровню, они не должны просто ждать, пока остальная группа выполнит предложенное упражнение. Таких детей рекомендуется спрашивать в первую очередь и давать им возможность ответить, если более слабый ребенок затрудняется это сделать. В этом случае общение с учителем на иностранном языке является образовательной практикой, способной повлиять на изменение качества преподавания и способа взаимодействия субъектов образовательного процесса [7].

Вторая подгруппа - это дети, которым необходимо основательно изучить материал всех трех этапов формирования лингвистического умения, их часто следует возвращать на предыдущий этап, пока тот или иной навык не будет освоен. Они, как правило, тянутся за более сильными и успешными учениками, хотя часто склоняются к формальному выполнению заданий. Эта группа наиболее многочисленна и основной сценарий урока планируется, исходя из потребностей этой группы. Они часто склонны просить поставить оценку за успешно выполненное домашнее задание, незначительные ответы на уроке и т.д. Этой группе требуется порой удлиненный период работы на этапе тренировки и перевод этих детей на финальный этап применения возможен после длительной и упорной работы. Эту группу следует опрашивать следом за детьми из более сильной, давая им возможность сосредоточиться и послушать других, поскольку хорошо известно, что дети прекрасно учатся друг от друга. Итак, основная задача педагога - обе- спечить этой подгруппе возможность тянуться за более сильными, получать заслуженное одобрение в случае успеха и ободрение в случае неудачи.

Молодой специалист представляет себе, что дети его группы условно разделяются на несколько подгрупп в соответствии с особенностями их развития и лингвистическими способностями.

Особо проблемной является третья группа детей, имеющих диагностированные отклонения в когнитивном и эмоциональном развитии от своих сверстников и очевидные индивидуальные особенности, требующие особые подходы к их обучению. Согласно закону об образовании РФ, эти дети могут обучаться в массовой школе, и школа обязана создать им соответствующие условия для обеспечения их индивидуального образовательного маршрута [1]. Первостепенной задачей учителя является создание на уроке доброжелательной обстановки, в которой комфортно и удобно будет работать каждому ребенку. Малейшие попытки насмешек, неуважительного отношения к детям из третьей группы должны неумолимо пресекаться учителем. Воздействуя на детей этой группы, целесообразно использовать методы работы с дошкольниками, что будет довольно продуктивно. Как указывает в своих трудах Маякова Е.В., важность в овладении языком дошкольниками определяется методикой преподавания, основанной интуитивно-практическом уровне речевого развития, без досконального разбора значения лексических единиц, грамматических конструкций, без изучения правил, когда можно просто говорить на иностранном языке [4].

Особо важно при работе с детьми любой группы уделять внимание формированию фонетической стороне речи. Необходимо отметить, что ученики начальной школы значительно легче других возрастных групп усваивают аспект практической фонетики иностранного языка, овладевают его ритмомелодикой. Ребенок осваивает основные тенденции и закономерности функционирования ритмомелодики в иностранной речи [2].

Дети должны изначально понимать, что в каждом человеке есть достоинства и недостатки и мы должны учиться сосуществовать в этом непростом мире. В этом главная цель инклюзивного образования. Педагог опирается на уроке на средства родного языка. Как указывает в своем исследовании Языкова Н.В., общаясь на родном языке, мы, как его носители, неосознанно придерживаемся единой системы значений. Возникает единое представление о картине мира, что и является основой общения [8].

Подобные практические занятия призваны помочь будущему молодому специалисту адаптироваться к непростым условиям работы в общеобразовательной школе в условиях инклюзивного образования. 


\section{ЛИТЕРАТУРА}

1. Федеральный закон от 29.12.12. № 273 Ф3 «06 образовании в Российской Федерации»// Собрание законодательства РФ 24.02.2020 № 8 - ст. 42.

2. Бурнакова К.Н., БоргояковаТ.Н. Ритмомелодическое оформление иноязычной речи: содержательный аспект/Казанская наука. №9, 2018. - Казань: Казанский Издат-ий Дом, с. 64-67.

3. Будник А.С. Формирование межкультурной коммуникативной компетенции старших школьников аудиовизуальными средствами. Известия РГПУ им. А.И. Герцена. 2012. № 150. С. 232-235

4. Маякова Е.В. Инновационная методика обучения английскому языку детей дошкольного возраста. Методист. - № 10. - 2017. С. $57-64$.

5. Петрова И.М. Культура речи и языковая личность педагога в контексте подготовки будущих учителей иностранного языка. Журнал: Язык и культура. М.: 000 «Центр развития научного сотрудничества», 2015.

6. Тарева Е.Г. Обучение языку и культуре: инструмент «мягкой силы»? Вестник Московского городского педагогического университета. Серия: Филология. Теория языка. Языковое образование. 2016. № 3(23). С. 94-101.

7. Тарева Е.Г. Развитие лингвообразовательных практик: оптимистичная проекция. Вестник Московского городского педагогического университета. Серия: Филология. Теория языка. Языковое образование. 2015. № 2 (18). С. 75-85.

8. Языкова Н.В. Культура и обучение иностранным языкам: лингводидактический аспект. Вестник Московского городского педагогического университета. Серия: Филология. Теория языка. Языковое образование. 2009. № 1 (3). С. 95-100.

\section{๑ Апарина Юлия Игоревна (juliaparina@mail.ru).}

Журнал «Современная наука: актуальные проблемы теории и практики»

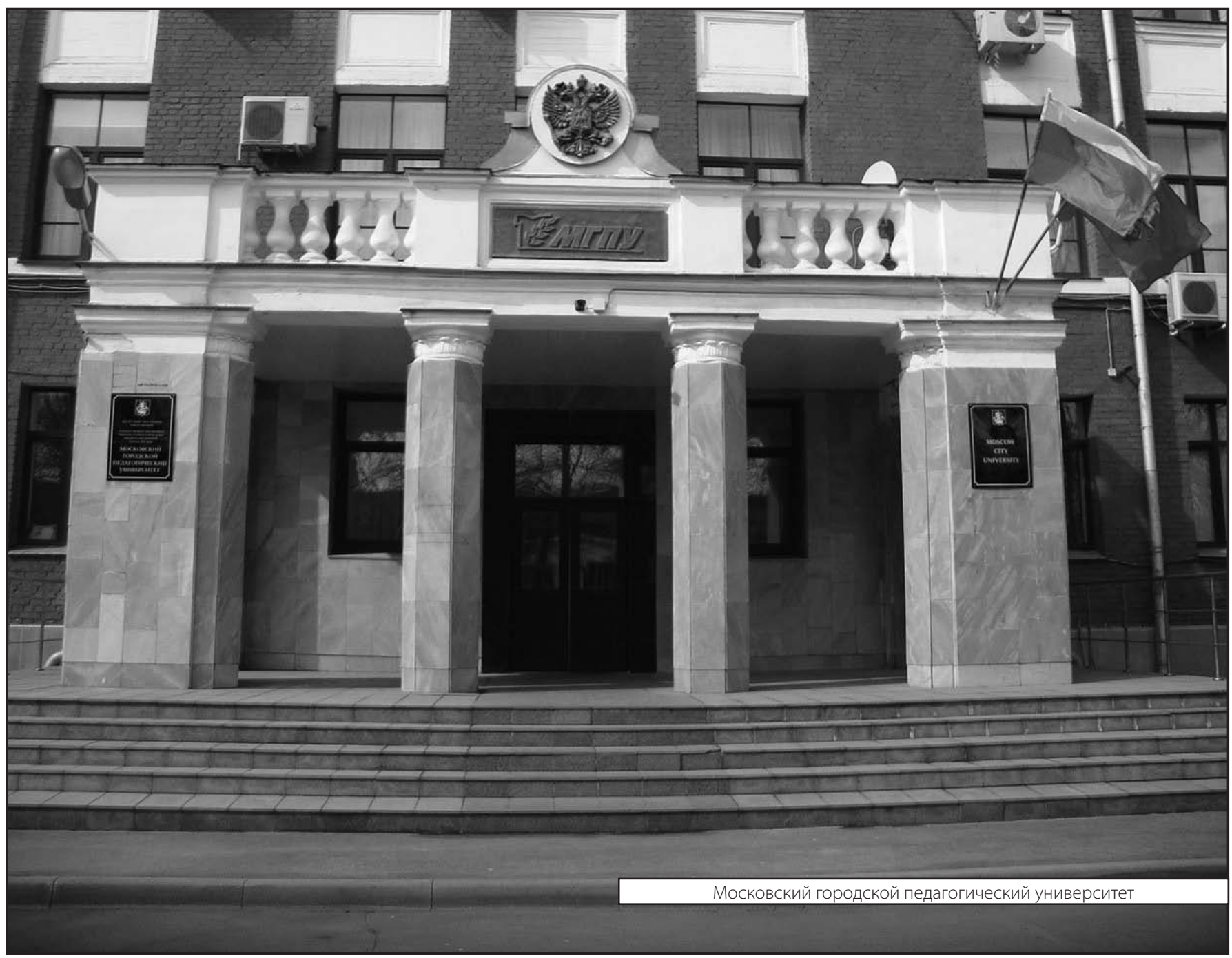

